\title{
Modelling Techniques to Improve the Quality of Food Using Artificial Intelligence
}

\author{
Varsha Sahni $\left(\mathbb{D},{ }^{1}\right.$ Sandeep Srivastava $\mathbb{D D}^{2}$ and Rijwan Khan $\mathbb{D i}^{3}$ \\ ${ }^{1}$ Department of Computer Science and Engineering, CT Institute of Engineering, Management and Technology, Shahpur, \\ Jalandhar 144020, Punjab, India \\ ${ }^{2}$ MCA Department, GL Bajaj Institute of Technology \& Management, Greater Noida 201306, India \\ ${ }^{3}$ Department of Computer Science and Engineering, ABES Institute of Technology, Ghaziabad 201009, India
}

Correspondence should be addressed to Rijwan Khan; rijwankhan786@gmail.com

Received 27 April 2021; Revised 1 July 2021; Accepted 17 July 2021; Published 29 July 2021

Academic Editor: Alessandra Durazzo

Copyright () 2021 Varsha Sahni et al. This is an open access article distributed under the Creative Commons Attribution License, which permits unrestricted use, distribution, and reproduction in any medium, provided the original work is properly cited.

\begin{abstract}
Artificial intelligence (AI), or AI/machine vision, is assuming an overwhelming part in the realm of food handling and quality affirmation. As indicated by Mordor Intelligence, AI in the food and refreshments market is required to enlist a CAGR of $28.64 \%$, during the conjecture time frame 2018-2023. Artificial intelligence makes it workable for PCs to gain as a matter of fact, investigate information from the two data sources and yields, and perform most human assignments with an improved level of accuracy and proficiency. Here is a concise gander at how AI is expanding sanitation and quality activities. This exploration has along these lines tried to furnish policymakers with a way to assess new and existing strategies, while likewise offering a reasonable premise through which food chains orders can be made stronger through the thought of the executive's practices and strategy choices. This survey centers on the AI applications according to four mainstays of food security that is food accessibility, food availability, food use, and strength.
\end{abstract}

\section{Introduction}

Quick development of populace, reducing characteristic assets, environmental change, contracting rural grounds, and unbalanced business sectors are making the worldwide food frameworks rather unreliable. In this manner, current farming and food frameworks ought to be more gainful regarding yield, effective in activity, tough to environmental change, and maintainable for the people in the future. Therefore, the need of an innovative change is more prominent than any time in recent memory. Being a new headway in computer sciences, artificial intelligence (AI) has the ability to address the difficulties of this new worldview. Subsequently, understanding the significance and relevance of AI in farming and food area could be essential in the excursion towards accomplishing worldwide food security [1]. The major goal of this study is to create artificial intelligence and methodology for assessing and optimizing food quality and safety initiatives in the food sector. The cost-effectiveness of the approaches examined in this study is as follows:

(a) Aspects of general technical and economic importance to consider when evaluating food quality and safety improvements

(b) Quantification of the relative efficacy of various AI techniques for increasing food quality with growth focus on the farm stage

(c) Optimal (lowest cost) AI techniques for enhancing food quality at various stages

(d) The impact of farm scale on additional expenses associated with implementation of AI techniques to improve the food quality and their distribution throughout various stages of the supply chain

This audit centers around the AI applications corresponding to four mainstays of food security (food accessibility, food availability, food use, and strength) as 
characterized by FAO, in detail. The AI innovations are being applied worldwide in every one of the four mainstays of food security despite the fact that it has been one of the more slow received advancements contrasted with the rest. On the other hand, it warrants investigating the abilities of AI and their present effect on the food frameworks. It is prominent that $\mathrm{AI}$ innovation has a critical task to carry out later on the cultivation area. The overall $\mathrm{AI}$ in cultivation market is required to arrive at USD 2,075 million by 2024 . Present article uncovers how AI innovations could profit worldwide farming and food area and looks at the ways by which AI can address the noticeable. Quality affirmation is acquiring conspicuousness since quality ascribes are by and large more exceptionally esteemed by governments, buyers, and organizations. Some food handling ascribes incorporated the accompanying terms described in Table 1. This higher valuation is inciting more deliberate quality affirmation by food organizations and more guidelines by government. Simultaneously, guidelines are under nearer investigation both locally and universally [2]. As requests for administrative responsibility have expanded, governments are progressively needed to utilize hazard appraisal and advantage cost investigation to assess whether existing or proposed food guidelines improve public government assistance.

The first necessary dimension in order to achieve food security is availability, which indicates the presence of food in a country through all forms of domestic production, food stocks, imports, and food aid [4]. The availability and access to food alone is not adequate, as people need to have a "safe and nutritious food." Sufficient energy should be there in order to engage the daily physical activities after consumption of foods. Adequate sanitary facilities to avoid the spread of diseases, safe drinking water, and the awareness of food preparation and food storage are also included. Utilization, which is the third dimension, therefore, covers the diverse aspects by combining consumers' understanding on which food to select, how to prepare it, and store them [5]. Food stability must be present at all times to exist the availability, access, and utilization of the food security. This fourth dimension highlights the importance to reduce the possibility of adverse effects on the other three dimensions [6].

Being a huge field with numerous applications, AI is likewise perhaps the most confounded innovations to chip away at. Machines characteristically are not more brilliant; a great deal of registering force and information are needed to engage them to reproduce human reasoning. A bunch of innovative and logical advances have prompted the development in the utilization of AI in genuine applications in different fields because of the huge increment of information with high computational force and huge stockpiling to enable them to reproduce human reasoning [7]. It is conceivable that a machine gains from its experience by changing their reactions dependent on new data sources given, playing out the human-like undertakings. The machines can be prepared to deal with a lot of information and perceive an example in them. At long last, AI is a data processing framework or computational framework that
TABLE 1: Quality affirmation handling different attributes of food quality.

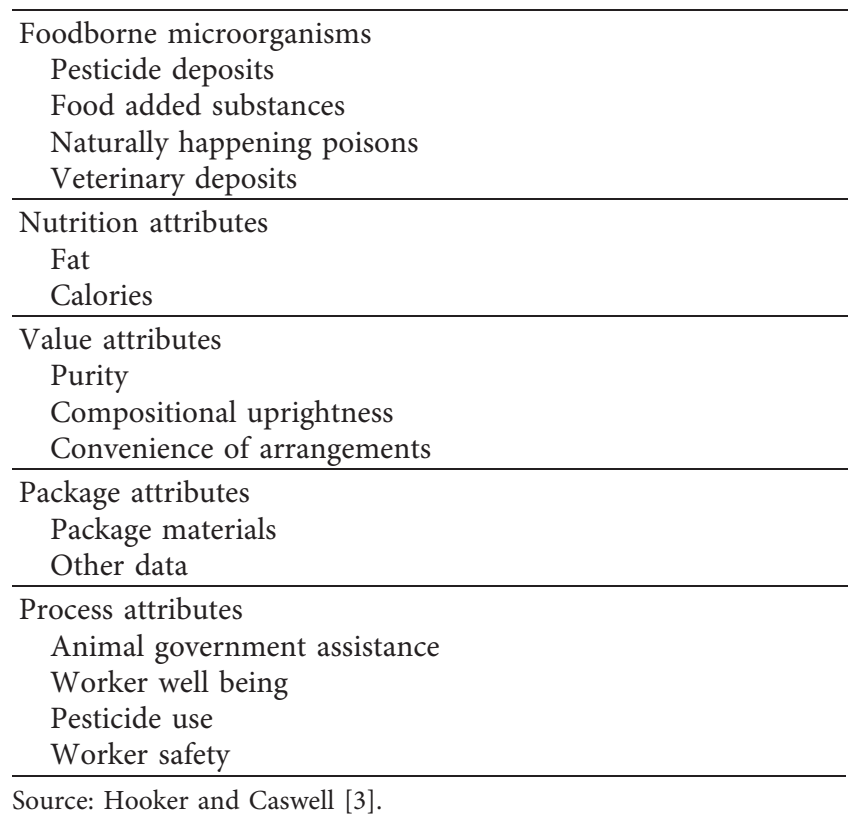

accepts information as data sources and interacts with them to prompt an easy to understand yield [8].

\section{Role of Artificial Intelligence Robotics in Food Safety}

By using the technology of artificial intelligence robotics, the agriculture sector would need to increase its productivity by about $70 \%$. To successfully achieve this, in Figure 1(a), a robotic technology will need to be a core unit to secure the quality of food in the food industry. AI has a vital role to play in future food production as shown in Figure 1(b). The robotics are also the part of artificial intelligence [9].

Food and refreshment organizations are moving quick utilizing innovation for activities and calculated efficiencies and onto how to meet user's requirements [10]. The prominent players in the industry have embraced artificial intelligence to maintain strong empathy with their audience. Rarely, has a crisis pushed the adoption of a technology in the way that $\mathrm{AI}$ in the food business is doing right now. The business of cultivating and selling high-quality food to consumers is being disrupted to a degree that has not been seen since the last pandemic, which occurred over a century ago. It is becoming increasingly clear that our food system was not adequately prepared ("antifragile") for the COVID19 -induced disaster. No germs and high-quality food has been prepared by this artificial intelligence robotics scheme, as shown in Figure 1(b).

The continuing deconstruction and automation of the food supply process demonstrates that we are entering a new normal and that returning to the old reality would be impossible. Robots, augmented reality, virtual reality, threedimensional printing, sensors, machine vision, drones, blockchain, and the Internet of things are all altering the food industry, but they all have one thing in common: 


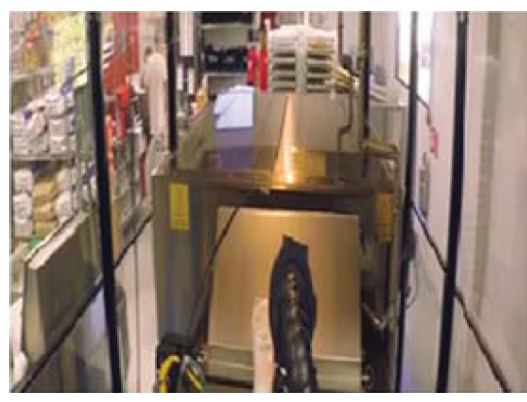

(a)

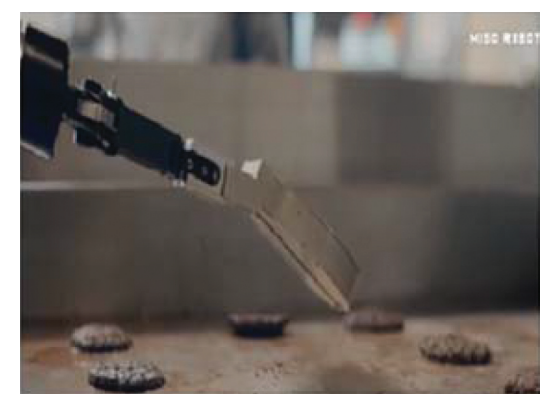

(b)

FIgure 1: (a) A robotic workforce to secure the food quality. (b) AI role to bake cookie.

artificial intelligence is the secret code or sauce underlying them all. As the world develops post-COVID, the application of AI to increase food production is quickening, and demands of speed, efficiency, and sustainability are rising in tandem with the quickly growing population.

\section{Applications of Artificial Intelligence with Its Drawbacks and Solution to These Challenges}

Artificial intelligence is transforming several sectors, including government, medicine, advert, and finance to name a few that have adopted this technology. By learning the intricacies involved with big data analytics and AI, the food and beverage industry has begun utilizing the numerous predictive analysis applications offered by this technology. A fascinating certainty we found is that the worldwide AI market in food and drink organizations is assessed to develop yearly at an accumulate development pace of $42 \%$ before 2021. This has become evident by the increasing amount of food companies that are using artificial intelligence to generate more revenue and improve their productivity [11]. For the first time, the light of technology has dawned dramatically on the food industry and has been implemented without any hesitation. Artificial intelligence is now known to be impacting many aspects of the industry such as financial, production, distribution, marketing, consumption, packaging, and storage. To give a better explanation of the extensive usage of AI in food manufacturing, processing, and distribution, here are a few notable highlights [12].

\section{Sorting}

Sorting food requires extra attention that is paid to the specific details of the product, for example, size or colour. These factors help food companies to make well-guided decisions on the processing of various foods that will ultimately increase the purchase rate of consumers.

Figure 2 shows the companies in the food industry, such as TOMRA sorting food (tomatoes), are among the few that take the advantage of artificial intelligence to develop machines that significantly improve the sorting of food [13]. These technology-inclined systems are sensor based and use features such as cameras and near-infrared sensors to visualize food products with human perception.

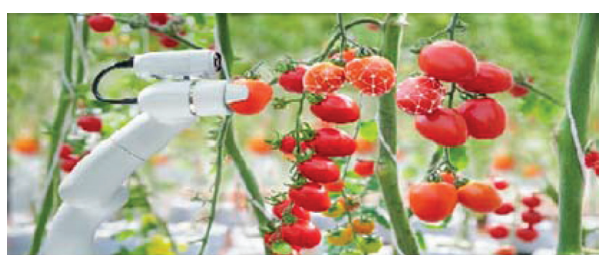

FIGURE 2: AI-based robot sorting the quality of tomato.

\section{Algorithm for AI-Based Robot Sorting the Quality of Tomato}

Step 1: capture image and capture the softness value

Step 2: predict type of tomato using image processing AI technique

Step 3: confirm prediction of AI with the softness value. Step 4: if confirmed, perform steps 5-7

Step 5: if tomato is damaged, pick it and discard it

Step 6: if tomato is not prepared, leave it

Step 7: if tomato is prepared, pick it and store it

\section{Execution of Individual Cleanliness Propensities by Workers}

The significance of guaranteeing that workers in food and refreshment organizations take important individual cleanliness careful steps could not possibly be more significant. Computerized reasoning empowers organizations to rapidly identify any failures in this facet and kill them for improved food handling. In Figure 3, several CCTV cameras are installed in the restaurant; this is just the advanced feature of the artificial intelligence. With this feature of artificial intelligence, the use of special cameras equipped with facial recognition and object recognition feature to ascertain if workers are committed to keeping the laws of food safety $[14,15]$.

\section{Reducing Equipment Repair and Maintenance Cost}

Any professional in the food industry knows how much of their company's resources go into cleaning processing machines and also repairing them. Ongoing research 


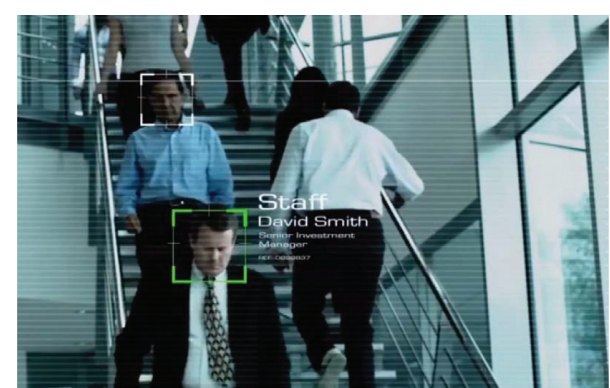

Figure 3: Investigation done via AI.

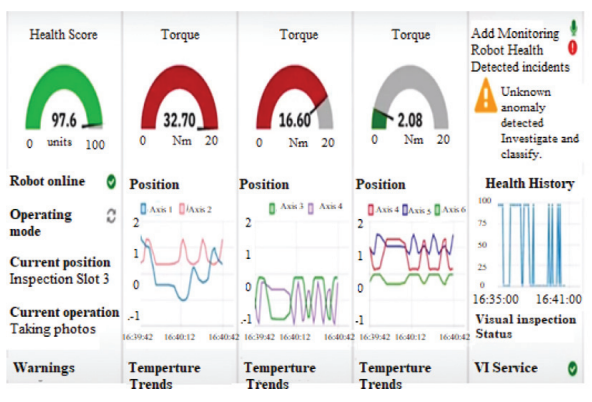

Figure 4: Application of artificial intelligence. projects suggest that a system known as the self-optimizingclear-in-place (SOCIP) which can improve cleaning time and drastically reduce resources used for cleaning including water [16]. In Figure 4, the artificial intelligence technology uses features such as ultrasonic sensing and optical fluorescence imaging to detect the tiniest amount of food leftover and microbial debris present in the equipment. This aids the optimization of the cleaning/maintenance process. Organizations can likewise use man-made brainpower in the part of machine fix and intermittent ideal working. It can rapidly identify any piece of hardware that is defective and separate them for instantaneous substitution of its corrupted apparatus. This will ultimately lead to improved employee efficiency and human resource management as there is a much better system in place to provide early detection of any fault [17].

\section{Optimized Supply Chain Management}

The food industry can use artificial intelligence to minimize delays and maximize profit margins by providing close monitoring of energy supply chain operation. This also helps companies to forecast for better management of pricing and stock products accurately. With growing concerns about transparency, artificial intelligence has also been utilized to track products from the farm to consumers to ensure transparency [18]. The flow of products will be cost-effective and streamlined in the best way possible with the adoption of this technique into food production and distribution.

\section{Revolutionizing the Whole in Store Shopping Experience with New Products}

Based on the available demographic data and statistics available, many food companies have been able to provide location-specific varieties of food flavour combinations that are targeted at a preferred group of consumers. By intently observing discussions via web-based media and utilizing man-made reasoning to break down burns through information and distinguish notions or conduct that are pivotal, in building positive encounters and in the turn of events and plan of new product offerings. This has proven to be an immense contribution to the food industry because companies can now offer unlimited forms of flavour combos, spices, and ingredients $[18,19]$.

\section{Personalized Customer Service}

The consumer favour a more customized insight as they shop utilizing visit boxes or voice aide fuelled by characteristic language handling, and organizations can tap buyer shopping information and history to give a hypercustomized and computerized client assistance experience. Using these predictive analysis technology provided by artificial intelligence solution providers, food companies can monitor on what decisions customers do overtime and what food they always reorder [20]. This ensures that the consumers are provided with a personalized feed containing their preferred food option.

\section{Better Farming Conditions}

It would be every heart-warming that the farmer could cultivate better food under optimal growth factors. Companies have already begun to research how they can apply this feature of artificial intelligence technology to better suit the farmers [20]. One of company known as Sentiment aims to invent a system that can create growing conditions where the effects of factors such as light intensity, temperature, salinity, and water stress on basil can be carefully checked (Figure 5). As of yet, progress only being made in the lab is looking to come up with specific "ingredients" for making perfect foods. Modern applications of artificial intelligence in the food sector include achieving significant reductions in the downtime, reducing consumer friction at the point of sale, speed up of manual tasks, and improving workerovertime ratio to name a few [21].

\section{Challenges of Artificial Intelligence and Available Solution}

So, with all the diverse ways listed above on how artificial intelligence is improving the food industry, it might hit you like a ton of bricks to hear that this amazing technology has also got its coins. While there are many benefits, there are just as many challenges. Companies have to decide whether to buy or build this technology, and ideally, food companies would develop their own unique in-house technology systems. However, to be pragmatic, a lot goes into acquiring these systems. A portion of the difficulties that join utilizing man-made consciousness in the food business include the following. 


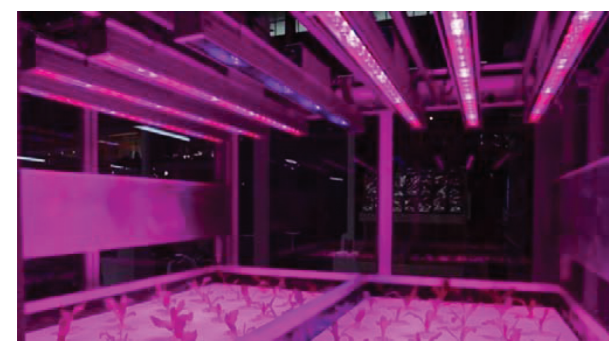

FIgURE 5: Farming done via AI.

12.1. Cost. Potential adapters face numerous difficulties with the price being the biggest among them and getting buy-in for these types of tech systems.

12.2. Integration Issues. It is never easy to integrate new technologies. This also works similar for the integration of artificial intelligence in food companies.

12.3. Proprietary Date. With the right proprietary date, food and beverage companies may not be talented to construct artificial erudition models that can execute. Given the above fundamental challenges, we will provide two solution ideas, especially for large companies with much capital that can be invested into adopting artificial intelligence technology. Food organizations that have effectively settled information investigation and a group of expert engineers can go on to securely fabricate their own man-made consciousness stage. You do not want to jump into making this decision if your company's team of developers lacks the required competency to match up with the in-house artificial intelligence system. They should be skilled enough to keep this system always updated to avoid any future troubles.

Various companies that lack such resources should find food and beverage solution providers that have already established artificial intelligence systems which will improve the front-end process and back-end process in your company. A few examples of these solution providers are SAP and bundled solutions built for food and beverage distribution. $75 \%$ of millennial in the US and UK would desire to utilize artificial intelligence innovation to get better help with arranging and preparing strong meals. Artificial intelligence is growing at a rapid pace and we have witnessed more companies within the food and beverage industry that are investing in artificial intelligence solutions for better performance. The predictive analysis provided by this cuttingedge tech is being used to resolve various critical problems in this industry. A lot of these companies have gone a step ahead to combine other areas of artificial intelligence with predictive quality analytics to create new opportunities to develop more potential products for the future $[20,21]$.

\section{COVID-19 Pandemic and the Food Security in the Country}

The recent COVID-19 pandemic has also reiterated the importance of food security particularly for developing nations. It has brought the global economy to a precarious position where Sri Lanka also has been impacted considerably at all levels. Almost all industries were negatively affected, apart from some essential services, such as water, electricity, fuel, and those producing food (farming) and medical supplies. Continuation of food production as an essential service was a crucial decision taken by the authority in order to assure food availability and accessibility [22]. However, the doss distribution took a longer time to return to normalcy. Under new normal situation, the working culture has now changed to the mode of "Work from Home." Hence, there is a need to redefine the agriculture profession, and technological needs to achieve food security based on the new needs. In such context, we firmly believe that AI applications together with recent advancement in technology have a bigger role to play. As the world develops postCOVID, the application of AI to increase food production is quickening, and demands of speed, efficiency, and sustainability are rising in tandem with the quickly growing population. Here are six instances of food sector players that have implemented AI and demonstrated how it has boosted their growth or even revolutionized the way they operate [23].

13.1. Processing. Food processing is a labour-intensive enterprise, but one where AI can increase production and minimize waste by replacing employees on the line whose sole job is to detect products that are not appropriate for processing. This form of fast decision-making necessitates the use of the senses of sight and scent, as well as the capacity to adjust to changing conditions. AI adds even more value to the table with augmented vision, which analyses data streams that are either accessible to human senses or where the volume of data is overwhelming.

13.2. Food Hygiene. AI can help to reduce the presence of diseases and identify poisons in food production.

13.3. Efficiency in the Supply Chain. While smart devices are being used to replace human labour, technology is also being used to replace human work. Food apps, drone and robot deliveries, and self-driving cars are all new methods to bring information and food to customers, and they all rely on AI.

13.4. Predicting Consumer Trends and Patterns Is a Difficult Task. AI enables businesses to stay competitive in the market by responding to diverse popular waves of diverse trends and creating market predictions.

Restaurants: following this year's COVID-19 epidemic, the future of eateries is in risk. The rise of online-based meal delivery services has shifted the focus away from the physical experience of dining establishments.

Creating more nutritious foods: for a long time, many people have believed that food equals health, but now, that we have a better understanding of human, plant, and animal genomes, it is becoming a reality. As the world progresses toward precision nutrition, changes in consumer tastes are providing potential for AI in food. One example is the increased desire for plant-based alternatives to animal protein. Creative AI 
TABLE 2: A summary of AI applications in the four pillars of the food security.

\begin{tabular}{|c|c|c|c|c|c|}
\hline Pillar & Application & Author & Technique & Remarks & $\begin{array}{l}\text { Practical use of } \\
\text { the application }\end{array}$ \\
\hline \multirow{19}{*}{ Availability } & $\begin{array}{l}\text { Paddy land leveling } \\
\text { system }\end{array}$ & Si et al. [1] & Fuzzy logic & $\begin{array}{c}\text { Fuzzy system in the controller } \\
\text { judges the land level }\end{array}$ & $\begin{array}{c}\text { Land } \\
\text { preparation }\end{array}$ \\
\hline & $\begin{array}{l}\text { Contaminated soil } \\
\text { classificatory tool }\end{array}$ & Lopez et al. [2] & Fuzzy logic & $\begin{array}{l}\text { Greater accuracy over typical } \\
\text { computer-based models }\end{array}$ & $\begin{array}{l}\text { Land and crop } \\
\text { selection }\end{array}$ \\
\hline & $\begin{array}{l}\text { Stem water potential } \\
\text { estimator }\end{array}$ & Valdes-Vela et al. [29] & Fuzzy logic & $\begin{array}{l}\text { Greater approximation power } \\
\text { compared to other models }\end{array}$ & $\begin{array}{l}\text { Water } \\
\text { management }\end{array}$ \\
\hline & $\begin{array}{l}\text { Soybean aphid control } \\
\text { system }\end{array}$ & Peixoto et al. [6] & Fuzzy logic & $\begin{array}{l}\text { Predict the timing and release of } \\
\text { predators for the biological } \\
\text { control }\end{array}$ & Pest \\
\hline & $\begin{array}{l}\text { Image-based AI } \\
\text { management system } \\
\text { for wheat }\end{array}$ & Li et al. [7] & ANN (BPNN) & $\begin{array}{l}\text { Uses pixel labelling algorithms for } \\
\text { image strengthening }\end{array}$ & $\begin{array}{l}\text { Fertilizer } \\
\text { application } \\
\text { time decision }\end{array}$ \\
\hline & $\begin{array}{l}\text { Soil moisture } \\
\text { monitoring system }\end{array}$ & Athani et al. [8] & $\begin{array}{l}\text { IoT-enabled } \\
\text { Arduino sensors }\end{array}$ & $\begin{array}{l}\text { Vastly decreases the } \\
\text { manufacturing and maintenance } \\
\text { costs }\end{array}$ & $\begin{array}{l}\text { Reduction of } \\
\text { COP }\end{array}$ \\
\hline & $\begin{array}{l}\text { System for detecting } \\
\text { mature whiteflies on } \\
\text { rose leaves }\end{array}$ & Boissard et al. [10] & ML & $\begin{array}{l}\text { Reliable for rapid detection of } \\
\text { whiteflies }\end{array}$ & $\begin{array}{c}\text { Pest } \\
\text { management }\end{array}$ \\
\hline & $\begin{array}{l}\text { AI-assisted weed } \\
\text { identification system }\end{array}$ & $\begin{array}{l}\text { Tobal and Mokthar } \\
{[30]}\end{array}$ & ANN & $\begin{array}{l}\text { Minimize the time of } \\
\text { classification training and error }\end{array}$ & Weed control \\
\hline & $\begin{array}{l}\text { Weed identification } \\
\text { system in paddy fields }\end{array}$ & Barrero et al. [11] & ANN & Based on areal image analysis & Weed control \\
\hline & $\begin{array}{l}\text { Novel weed } \\
\text { management strategy }\end{array}$ & $\begin{array}{l}\text { Pérez-Harguindeguy } \\
\text { et al. [31] }\end{array}$ & ML & $\begin{array}{c}\text { Combines UAVs, image } \\
\text { processing, and ML }\end{array}$ & Weed control \\
\hline & $\begin{array}{l}\text { Field weed } \\
\text { identification system }\end{array}$ & Ebenso et al. [32] & ANN & $\begin{array}{l}\text { Improves crop/weed species } \\
\text { discrimination }\end{array}$ & Weed control \\
\hline & $\begin{array}{l}\text { Expert system for } \\
\text { diagnosis of potato } \\
\text { diseases }\end{array}$ & Boyd and Sun [33] & $\begin{array}{c}\text { Rule-based } \\
\text { computer program }\end{array}$ & $\begin{array}{c}\text { Can diagnose eleven pathogenic } \\
\text { diseases and six nonpathogenic } \\
\text { diseases }\end{array}$ & $\begin{array}{c}\text { Disease } \\
\text { management }\end{array}$ \\
\hline & $\begin{array}{c}\text { Expert system for } \\
\text { diagnosing diseases in } \\
\text { rice plant }\end{array}$ & Sarma et al. [34] & $\begin{array}{c}\text { Rule-based } \\
\text { computer program }\end{array}$ & $\begin{array}{l}\text { Based on logic programming } \\
\text { approach }\end{array}$ & $\begin{array}{l}\text { Disease } \\
\text { management }\end{array}$ \\
\hline & $\begin{array}{c}\text { Leaf image } \\
\text { classification system }\end{array}$ & Sladojevic et al. [35] & ANN & $\begin{array}{l}\text { Uses deep convolutional } \\
\text { networks }\end{array}$ & $\begin{array}{c}\text { Disease } \\
\text { management }\end{array}$ \\
\hline & $\begin{array}{l}\text { System for diagnosing } \\
\text { diseases of oilseed- } \\
\text { crops }\end{array}$ & Chaudhary et al. [36] & Fuzzy logic & $\begin{array}{l}\text { Much faster inference compared } \\
\text { to earlier models }\end{array}$ & $\begin{array}{c}\text { Disease } \\
\text { management }\end{array}$ \\
\hline & $\begin{array}{l}\text { System for rice yield } \\
\text { prediction }\end{array}$ & Ji et al. [37] & ANN & $\begin{array}{l}\text { More accurate than linear } \\
\text { regression models for the yield } \\
\text { predictions }\end{array}$ & $\begin{array}{l}\text { Yield prediction } \\
\text { (decision } \\
\text { making) }\end{array}$ \\
\hline & $\begin{array}{l}\text { System for cotton yield } \\
\text { prediction }\end{array}$ & Zhang et al. [38] & ANN & $\begin{array}{l}\text { More realistic trends versus input } \\
\text { factors and predicted yields }\end{array}$ & $\begin{array}{l}\text { Yield prediction } \\
\text { (decision } \\
\text { making) }\end{array}$ \\
\hline & $\begin{array}{l}\text { System for wheat yield } \\
\text { pre }\end{array}$ & Ruß et al. [39] & ANN & $\begin{array}{c}\text { Uses cheaply available in-season } \\
\text { data. }\end{array}$ & $\begin{array}{l}\text { Yield prediction } \\
\text { (decision } \\
\text { making) }\end{array}$ \\
\hline & $\begin{array}{l}\text { System for jute yield } \\
\text { prediction }\end{array}$ & Rahman and Bala [40] & ANN & $\begin{array}{l}\text { Could be used to predict } \\
\text { production at different locations }\end{array}$ & $\begin{array}{l}\text { Yield prediction } \\
\text { (decision } \\
\text { making) }\end{array}$ \\
\hline
\end{tabular}


TABLE 2: Continued.

\begin{tabular}{|c|c|c|c|c|c|}
\hline Pillar & Application & Author & Technique & Remarks & $\begin{array}{l}\text { Practical use of } \\
\text { the application }\end{array}$ \\
\hline \multirow{9}{*}{ Accessibility } & Food desert identifier & Zhao [41] & $\begin{array}{c}\text { Big data analytics } \\
\text { and ML }\end{array}$ & Locates areas with low food access & $\begin{array}{c}\text { Decision } \\
\text { making }\end{array}$ \\
\hline & Food desert identifier & Amin et al. [42] & ML & $\begin{array}{c}\text { Detects food deserts and food } \\
\text { swamps with a prediction } \\
\text { accuracy of } 72 \%\end{array}$ & $\begin{array}{c}\text { Decision } \\
\text { making }\end{array}$ \\
\hline & $\begin{array}{l}\text { Decision tool to } \\
\text { evaluate the } \\
\text { performance of } \\
\text { agriculture food value } \\
\text { chain }\end{array}$ & Liu et al. [43] & Fuzzy logic & $\begin{array}{c}\text { Integrates TFN, AHP, and } \\
\text { TOPSIS }\end{array}$ & $\begin{array}{l}\text { Decision } \\
\text { making }\end{array}$ \\
\hline & $\begin{array}{l}\text { Forecasting of food } \\
\text { production }\end{array}$ & Sharma and Patil [44] & Fuzzy logic & $\begin{array}{l}\text { Forecast the production and } \\
\text { consumption of rice }\end{array}$ & $\begin{array}{c}\text { Decision } \\
\text { making }\end{array}$ \\
\hline & $\begin{array}{l}\text { Forecasting of food } \\
\text { production }\end{array}$ & Yan et al. [45] & ML & $\begin{array}{l}\text { Uses ANN, SVM, GP, and GPR to } \\
\text { forecast future milk yield }\end{array}$ & $\begin{array}{c}\text { Decision } \\
\text { making }\end{array}$ \\
\hline & $\begin{array}{l}\text { Supply chain } \\
\text { optimization }\end{array}$ & $\begin{array}{c}\text { Cheraghalipour et al. } \\
{[46]}\end{array}$ & Evolutionary ML & $\begin{array}{l}\text { Reduce held inventory and cost in } \\
\text { supply chains }\end{array}$ & $\begin{array}{l}\text { Efficient food } \\
\text { distribution }\end{array}$ \\
\hline & $\begin{array}{l}\text { Supply chain } \\
\text { optimization }\end{array}$ & Ketsripongsa et al. [47] & Evolutionary ML & $\begin{array}{l}\text { Used for transportation } \\
\text { scheduling of seafood and milk } \\
\text { products }\end{array}$ & $\begin{array}{l}\text { Efficient food } \\
\text { distribution }\end{array}$ \\
\hline & $\begin{array}{l}\text { Supply chain } \\
\text { forecasting }\end{array}$ & Olan et al. [48] & ANN & $\begin{array}{l}\text { Forecast the results of perishable } \\
\text { food transportation }\end{array}$ & $\begin{array}{c}\text { Decision } \\
\text { making }\end{array}$ \\
\hline & $\begin{array}{l}\text { System for preparing } \\
\text { and dispensing food }\end{array}$ & Sharma et al. [49] & Robotics & $\begin{array}{c}\text { Extremely useful in pandemic } \\
\text { situations like COVID-19 }\end{array}$ & $\begin{array}{l}\text { Efficient food } \\
\text { distribution }\end{array}$ \\
\hline \multirow{5}{*}{ Utilization } & $\begin{array}{c}\text { Cassava roots storage } \\
\text { system }\end{array}$ & Babawuro et al. [50] & Fuzzy logic & $\begin{array}{l}\text { Uses an intelligent temperature } \\
\text { control technique }\end{array}$ & $\begin{array}{c}\text { Postharvest } \\
\text { quality control }\end{array}$ \\
\hline & Fruit storage system & Morimoto et al. [51] & $\begin{array}{l}\text { Fuzzy logic and } \\
\text { ANN }\end{array}$ & $\begin{array}{l}\mathrm{RH} \text { inside the storage house is } \\
\text { controlled }\end{array}$ & $\begin{array}{l}\text { Postharvest } \\
\text { quality control }\end{array}$ \\
\hline & Potato storage system & Gottschalk [52] & Fuzzy logic & Highly energy efficient & $\begin{array}{l}\text { Postharvest } \\
\text { quality control }\end{array}$ \\
\hline & $\begin{array}{l}\text { Mechanical damage } \\
\text { detection of fruits }\end{array}$ & Vélez Rivera et al. [53] & $\begin{array}{l}\text { Hyperspectral } \\
\text { images and ML }\end{array}$ & $\begin{array}{l}\text { Used as a tool for the automatic } \\
\text { inspection and monitoring of } \\
\text { internal defects of fruits and } \\
\text { vegetables in postharvest quality } \\
\text { control laboratories }\end{array}$ & $\begin{array}{c}\text { Postharvest } \\
\text { quality control }\end{array}$ \\
\hline & $\begin{array}{c}\text { Assorting of fruits and } \\
\text { vegetables }\end{array}$ & Valdez [54] & $\begin{array}{l}\text { Computer vision } \\
\text { and deep learning }\end{array}$ & $\begin{array}{l}\text { Fast, reliable, and labor } \\
\text { inexpensive methods }\end{array}$ & $\begin{array}{c}\text { Reduce labor } \\
\text { requirement }\end{array}$ \\
\hline \multirow{3}{*}{ Stability } & \multirow[t]{2}{*}{$\begin{array}{l}\text { Water resource } \\
\text { management }\end{array}$} & Zahm et al. [56] & ANN & $\begin{array}{l}\text { Minimize the ground water } \\
\text { overexploitation and } \\
\text { groundwater remediation } \\
\text { through pump-treat-inject } \\
\text { technology }\end{array}$ & $\begin{array}{l}\text { Increasing } \\
\quad \text { water } \\
\text { availability }\end{array}$ \\
\hline & & Zahm et al. [56] & ANN & $\begin{array}{l}\text { Identify the reasons for spring } \\
\text { flow decrease }\end{array}$ & $\begin{array}{l}\text { Increasing } \\
\text { water } \\
\text { availability }\end{array}$ \\
\hline & $\begin{array}{l}\text { Supply chain quality } \\
\text { data integration } \\
\text { method }\end{array}$ & Wang [18] & $\begin{array}{l}\text { AI integration } \\
\text { method of block } \\
\text { chain technology }\end{array}$ & $\begin{array}{l}\text { Supply chain of agriculture } \\
\text { products }\end{array}$ & $\begin{array}{l}\text { Increasing } \\
\text { water } \\
\text { availability }\end{array}$ \\
\hline
\end{tabular}

AI, artificial intelligence; ANN, artificial neural networks; BPNN, back-propagation neural network; IoT, Internet of things; ML, machine learning.

applications have risen in response to challenges such as establishing consumer-acceptable flavour and texture features.

\section{Synthesis and Way Forward}

The synthesis and way forward towards the artificial intelligence plays the vital role in the examination. To achieve the high quality in food is the major agenda nowadays. The powerful techniques have to be applied. As discussed in this study, achieving food security is the ultimate objective of future agricultural and allied sectors. A thorough review on the applications of $\mathrm{AI}$ in food security indicates promising signs in this regard. Within the food sector, AI could uplift existing practices and strategies in order to achieve productivity and sustainability goals efficiently and effectively [24].

As FAO [25] clearly states, achieving food security relies on top of four key pillars. This article primarily focused on the applications of AI in these four vital areas of the food 
sector. There are many benefits of AI, which has been applied in the form of different tools and techniques that are user friendly and providing optimum results. These techniques are combined with other technological advancements and being applied into agricultural practices along the food value chain. Many different AI technologies have been adopted over a wide range of applications in the agriculture sector in many countries. Among those, as expected, fuzzy logic systems, ANN, and ML could be identified as the most frequently used technologies while being the pioneer concepts of this innovative branch of computer science. With the anticipated changes in trends in AI technology, we could expect differences in its complexion in applications in the future. As indicated in Table 1, many applications can be identified on the use of AI in the area of food availability. This is directly related with the objective of improving food production. As it provides direct benefits to all the stakeholders, most of the AI technology developers seem to have concentrated their efforts in this direction [26]. It would provide both short-term and long-term benefits. However, achievement of future food security does not depend solely on ensuring food availability. One of the key findings of this review is the lack of AI applications in other three pillars of food security. Nevertheless, many recent developments indicate the use of AI applications towards other three pillars of food security as well. If this promising trend continues, there is an expectation on the achievement national level food security [27]. The AI and agriculture seem two vastly different sciences. However, the evidence provided in this article suggests that the marriage between these two fields of study could yield huge positive impacts in meeting the global goal of food security $[9,28]$. Table 2 presents the four pillars of the food security based on artificial intelligence applications.

From Table 2, showing the most appropriate researchers ideas about the plant tracking system is being developed using a particular AI methodology. To construct a plant surveillance system for sensing and managing a plant development parameter, namely, relative humidity, a specific AI approach is being used. The system's performance is extremely predictable and accurate, according to the data collected. Plant humidity sensors are used to monitor changes in moisture and to adjust irrigation methods. These simple adjustments in irrigation procedures increase productivity while saving water. Effective irrigation management with plant water sensors requires focused monitoring of the sensors to get the water level when the data received is within the set range for the specific growing conditions. We can utilize neural networks to anticipate seasonal fluctuations and rainfall in a region, which will aid farmers in planning their future yield.

Asymmetric sensor node deployment, gathering of insufficiently useable information and data for food deserts, and a gap between the right dataset (of which blocks are true food deserts) [42] and surveyed data based on limited/inaccurate real-world data making decisions without $\mathrm{AI}$ is a difficult task.

The use of computer vision and deep learning technology in agriculture seeks to improve the quality of harvests and farmers' production. Assorting fruits and vegetables has an impact on the export market and quality evaluation at postharvest. TOMRA industry sorts the good quality tomatoes from defected tomatoes during harvesting or/and during the postharvesting phase, as shown in Figure 2. The goal of this article is to assist farmers with postharvest processing by determining whether modern AI approaches may assist in distinguishing healthy tomatoes from tomatoes with flaws [57-60].

\section{Conclusion}

The artificial intelligence approach provides efficient solution that helps to increase the lifetime of farming activities. Therefore, in farming, the concept of artificial intelligence is implemented which makes the task so effective and simple. One benefit of these computerized frameworks is that they offer consistent data across a scope of timescales, from hours to months, accordingly working with the advancement of models of cycles which might be explicit to a specific time span. Besides, these frameworks can promptly be utilized in business nurseries, so the inferred intelligent models are moderately simple to convey to a business setting where they can consequently be improved over the long moment.

\section{Data Availability}

No data were used to support this study.

\section{Conflicts of Interest}

The authors declare that they have no conflicts of interest.

\section{References}

[1] Y. Si, G. Liu, J. Lin, Q. Lv, and F. Juan, "Design of control system of laser leveling machine based on fussy control theory," in Proceedings of the International Conference on Computer and Computing Technologies in Agriculture, pp. 1121-1127, Springer, Wuyishan, China, August 2007.

[2] E. M. López, M. García, M. Schuhmacher, and J. L. Domingo, "A fuzzy expert system for soil characterization," Environment International, vol. 34, no. 7, pp. 950-958, 2008.

[3] N. H. Hooker and J. A. Caswell, "Trends in food quality regulation: implications for processed food trade and foreign direct investment," Agribusiness, vol. 12, no. 5, pp. 411-419, 1996.

[4] F. Riely, N. Mock, B. Cogill, L. Bailey, and E. Kenefick, Food Security Indicators and Framework for Use in the Monitoring and Evaluation of Food Aid Programs, Nutrition Technical Assistance Project (FANTA), Washington, DC, USA, 1999.

[5] R. L. Paula Elis de, P. F. Trugilho, A. Napoli, and M. L. Bianchi, "Characterization of residues from plant biomass for use in energy generation," Cerne, vol. 17, no. 2, pp. 237-246, 2011.

[6] M. S. Peixoto, L. C. Barros, R. C. Bassanezi, and O. A. Fernandes, "An approach via fuzzy systems for dynamics and control of the soybean aphid," in Proceedings of the 2015 Conference of the International Fuzzy Systems Association and the European Society for Fuzzy Logic and Technology (IFSA-EUSFLAT-15), September 2015.

[7] S. K. Li, X. M. Suo, Z. Y. Bai et al., "The machine recognition for population feature of wheat images based on BP neural 
network," Agricultural Sciences in China, vol. 1, no. 8, pp. 885-889, 2002.

[8] S. Athani, C. Tejeshwar, M. M. Patil, P. Patil, and R. Kulkarni, "Soil moisture monitoring using IoT enabled arduino sensorswith neural networks for improving soil management for farmers and predict seasonal rainfall for planning future harvest in North Karnataka-India," in Proceedings of the 2017 International Conference on I-SMAC (IoT in Social, Mobile, Analytics and Cloud)(I-SMAC), pp. 43-48, Palladam, Tamil Nadu, February 2017.

[9] N. Naumov, The Impact of Robots, Artificial Intelligence, and Service Automation on Service Quality and Service Experience in Hospitality, Emerald Publishing Limited, Bradford, UK, 2019.

[10] P. Boissard, V. Martin, and S. Moisan, "A cognitive vision approach to early pest detection in greenhouse crops," Computers and Electronics in Agriculture, vol. 62, no. 2, pp. 81-93, 2008.

[11] O. Barrero, D. Rojas, C. Gonzalez, and S. Perdomo, "Weed detection in rice fields using aerial images and neural networks," in Proceeedings of the the 2016 XXI Symposium on Signal Processing, Images and Artificial Vision (STSIVA), pp. 1-4, Bucaramanga, Colombia, August 2016.

[12] M. Barzegar, D. Zare, and R. L. Stroshine, "An integrated energy and quality approach to optimization of green peas drying in a hot air infrared-assisted vibratory bed dryer," Journal of Food Engineering, vol. 166, pp. 302-315, 2015.

[13] C. Beans, "Inner Workings: crop researchers harness artificial intelligence to breed crops for the changing climate," Proceedings of the National Academy of Sciences, vol. 117, no. 44, pp. 27066-27069, 2020.

[14] B. T. Bestelmeyer, G. Marcillo, S. E. McCord et al., "Scaling up agricultural research with artificial intelligence," IT Professional, vol. 22, no. 3, pp. 33-38, 2020.

[15] J. Qiao, M. O. Ngadi, N. Wang, C. Gariépy, and S. O. Prasher, "Pork quality and marbling level assessment using a hyperspectral imaging system," Journal of Food Engineering, vol. 83, no. 1, pp. 10-16, 2007.

[16] J. Qin, T. F. Burks, X. Zhao, N. Niphadkar, and M. A. Ritenour, "Multispectral detection of citrus canker using hyperspectral band selection," Transactions of the $A S A B E$, vol. 54, no. 6, pp. 2331-2341, 2011.

[17] A. Rady, N. Ekramirad, A. A. Adedeji, M. Li, and R. Alimardani, "Hyperspectral imaging for detection of codling moth infestation in GoldRush apples," Postharvest Biology and Technology, vol. 129, pp. 37-44, 2017.

[18] Y.-N. Wang, L. Jin, and H. Mao, “Farmer cooperatives' intention to adopt agricultural information technology-mediating effects of attitude," Information Systems Frontiers, vol. 21, no. 3, pp. 565-580, 2019.

[19] M. J. Widener and J. Shannon, "When are food deserts? Integrating time into research on food accessibility," Health \& Place, vol. 30, pp. 1-3, 2014.

[20] D. P. Withanage and B. W. R. Damayanthi, "Factors influencing the youths' interest in," Agricultural Entrepreneurship in Sri Lanka, vol. 9, no. 12, pp. 32-40, 2019.

[21] J.-C. Xu, M. Zhang, A. S. Mujumdar, and B. Adhikari, "Recent developments in smart freezing technology applied to fresh foods," Critical Reviews in Food Science and Nutrition, vol. 57, no. 13, pp. 2835-2843, 2017.

[22] B. Marambe and P. Silva, "A sixty-day battle to tackle food security-response of the Sri Lankan government to the COVID-19 pandemic," Sri Lanka Journal of Food and Agriculture, vol. 6, no. 1, 2020.
[23] M.-M. Janet, V. Nele, T.-C. Juan et al., "Understanding smallholder farmers' intention to adopt agricultural apps: the role of mastery approach and innovation hubs in Mexico," Agronomy, vol. 11, pp. 194-2, 2021.

[24] T. O. Ojo, L. J. S. Baiyegunhi, A. A. Adetoro, and A. A. Ogundeji, "Adoption of soil and water conservation technology and its effect on the productivity of smallholder rice farmers in Southwest Nigeria," Heliyon, vol. 7, no. 3, Article ID e06433, 2021.

[25] Food and Agriculture Organization, Food and Agriculture Organisation of the United Nations, Food and Agriculture Organization, Rome, Italy, 2008.

[26] K. Spanaki, E. Karafili, U. Sivarajah, S. Despoudi, and Z. Irani, "Artificial intelligence and food security: swarm intelligence of AgriTech drones for smart AgriFood operations," Production Planning \& Control, pp. 1-19, 2021.

[27] C. K. Koffi, A. Lourme-Ruiz, E. Bouquet et al., "The contributions of wild tree resources to food and nutrition security in sub-Saharan African drylands: a review of the pathways and beneficiaries," International Forestry Review, vol. 22, no. 1, pp. 64-82, 2020.

[28] C. Mbow, C. E. Rosenzweig, L. G. Barioni et al., Food Security, Frontiers, Lausanne, Switzerland, 2020.

[29] M. Valdés-Vela, I. Abrisqueta, W. Conejero, J. Vera, and M. C. Ruiz-Sánchez, "Soft computing applied to stem water potential estimation: a fuzzy rule based approach," Computers and Electronics in Agriculture, vol. 115, pp. 150-160, 2015.

[30] A. Tobal and S. A. Mokhtar, "Weeds identification using evolutionary artificial intelligence algorithm," Journal of Computer Science, vol. 10, no. 8, pp. 1355-1361, 2014.

[31] N. Pérez-Harguindeguy, S. Díaz, E. Garnier et al., "Corrigendum to: new handbook for standardised measurement of plant functional traits worldwide," Australian Journal of Botany, vol. 64, no. 8, pp. 715-716, 2016.

[32] E. E. Ebenso, N. O. Eddy, and A. O. Odiongenyi, "Corrosion inhibitive properties and adsorption behaviour of ethanol extract of piper guinensis as a green corrosion inhibitor for mild steel in $\mathrm{H}_{2} \mathrm{SO}_{4}$," African Journal of Pure and Applied Chemistry, vol. 2, no. 11, pp. 107-115, 2008.

[33] D. W. Boyd and M. K. Sun, "Prototyping an expert system for diagnosis of potato diseases," Computers and Electronics in Agriculture, vol. 10, no. 3, pp. 259-267, 1994.

[34] S. K. Sarma, K. R. Singh, and A. Singh, "An expert system for diagnosis of diseases in rice plant," International Journal of Artificial Intelligence, vol. 1, no. 1, pp. 26-31, 2010.

[35] S. Sladojevic, M. Arsenovic, A. Anderla, D. Culibrk, and D. Stefanovic, "Deep neural networks based recognition of plant diseases by leaf image classification," Computational Intelligence and Neuroscience, vol. 2016, Article ID 3289801, 11 pages, 2016.

[36] A. Chaudhary, S. Kolhe, and R. Kamal, "A hybrid ensemble for classification in multiclass datasets: an application to oilseed disease dataset," Computers and Electronics in Agriculture, vol. 124, pp. 65-72, 2016.

[37] B. Ji, Y. Sun, S. Yang, S. Yang, and J. Wan, "Artificial neural networks for rice yield prediction in mountainous regions," The Journal of Agricultural Science, vol. 145, no. 3, pp. 249261, 2007.

[38] L.-Z. Zhang, W. Van Der Werf, W.-X. Cao, B. Li, X. Pan, and J. H. J. Spiertz, "Development and validation of SUCROScotton: a potential crop growth simulation model for cotton," NJAS: Wageningen Journal of Life Sciences, vol. 56, no. 1-2, pp. 59-83, 2008. 
[39] G. Ruß, R. Kruse, M. Schneider, and P. Wagner, "Data mining with neural networks for wheat yield prediction," in Proceedings of the Industrial Conference on Data Mining, pp. 47-56, Springer, St. Petersburg, Russia, July 2008.

[40] M. M. Rahman and B. K. Bala, "Modelling of jute production using artificial neural networks," Biosystems Engineering, vol. 105, no. 3, pp. 350-356, 2010.

[41] Y. D. Zhao, Machine learning based identification of food desert effect in urbun development, Ph.D. thesis, Cleveland State University, Cleveland, OH, USA, 2020.

[42] M. D. Amin, B. Syed, and J. J. McCluskey, "Predicting access to healthful food retailers with machine learning," Food Policy, vol. 99, Article ID 101985, 2021.

[43] Y. Liu, C. Eckert, G. Yannou-Le Bris, and G. Petit, "A fuzzy decision tool to evaluate the sustainable performance of suppliers in an agrifood value chain," Computers \& Industrial Engineering, vol. 127, pp. 196-212, 2019.

[44] S. Sharma and S. V. Patil, "Key indicators of rice production and consumption, correlation between them and supplydemand prediction," International Journal of Productivity and Performance Management, vol. 64, no. 8, pp. 1113-1137, 2015.

[45] Y. Yan, C.-C. Feng, M. P.-H. Wan, and K. T.-T. Chang, "Multiple regression and artificial neural network for the prediction of crop pest risks," in Proceedings of the International Conference on Information Systems for Crisis Response and Management in Mediterranean Countries, pp. 73-84, Springer, Tunis, Tunisia, October 2015.

[46] A. Cheraghalipour, M. M. Paydar, and M. HajiaghaeiKeshteli, "A bi-objective optimization for citrus closed-loop supply chain using pareto-based algorithms," Applied Soft Computing, vol. 69, pp. 33-59, 2018.

[47] U. Ketsripongsa, R. Pitakaso, K. Sethanan, and T. Srivarapongse, "An improved differential evolution algorithm for crop planning in the northeastern region of Thailand," Mathematical and Computational Applications, vol. 23, no. 3, p. 40, 2018.

[48] F. Olan, S. Liu, J. Suklan, U. Jayawickrama, and E. O. Arakpogun, "The role of artificial intelligence networks in sustainable supply chain finance for food and drink industry," International Journal of Production Research, vol. 2021, Article ID 1915510, 16 pages, 2021.

[49] A. Sharma, P. Zanotti, and L. P. Musunur, "Drive through robotics: robotic automation for last mile distribution of food and essentials during pandemics," IEEE Access, vol. 8, pp. 127190-127219, 2020.

[50] A. Y. Babawuro, S. A. Umar, S. Fatai, M.-J. E. Salami, and S. Naim Sidek, "Fuzzy logic based intelligent temperature controller for cassava post-harvest storage system," in Proceedings of the International Conference on Artificial Intelligence, Electrical \& Electronics Engineering (AIEE-15), Kuala Lumpur, Malaysia, May 2015.

[51] T. Morimoto, W. Purwanto, J. Suzuki, and Y. Hashimoto, "Optimization of heat treatment for fruit during storage using neural networks and genetic algorithms," Computers and Electronics in Agriculture, vol. 19, no. 1, pp. 87-101, 1997.

[52] K. Gottschalk, L. Nagy, and I. Farkas, "Improved climate control for potato stores by fuzzy controllers," Computers and Electronics in Agriculture, vol. 40, no. 1-3, pp. 127-140, 2003.

[53] N. Vélez Rivera, J. Gómez-Sanchis, J. Chanona-Pérez et al., "Early detection of mechanical damage in mango using NIR hyperspectral images and machine learning," Biosystems Engineering, vol. 122, pp. 91-98, 2014.
[54] P. Valdez, "Apple defect detection using deep learning based object detection for better post harvest handling," 2020, https://arxiv.org/abs/2005.06089.

[55] S. Sadeghfam, R. Daneshfaraz, R. Khatibi, and O. Minaei, "Experimental studies on scour of supercritical flow jets in upstream of screens and modelling scouring dimensions using artificial intelligence to combine multiple models (AIMM)," Journal of Hydroinformatics, vol. 21, no. 5, pp. 893-907, 2019.

[56] F. Zahm, P. Viaux, L. Vilain et al., Farm Sustainability Assessment Using the IDEA Method. From the Concept of Farm Sustainability to Case Studies on French Farms, International Institute for Sustainable Development, Chicago, IL, USA, 2006.

[57] J. R. Porter, L. Xie, A. J. Challinor et al., Food Security and Food Production Systems, The Commonwealth Scientific and Industrial Research Organisation, Canberra, Australia, 2014.

[58] P. Pawar, V. Turkar, and P. Patil, "Cucumber disease detection using artificial neural network," in Proceedings of the 2016 International Conference on Inventive ComputationTechnologies (ICICT), vol. 3, pp. 1-5, IEEE, New York,NY, USA, August 2016.

[59] P. Phaiju, "Towards food security through artificial neural network," Journal of Science and Engineering, vol. 6, pp. 71-77, 2019.

[60] M. Bagheri, K. Al-Jabery, D. Wunsch, and J. G. Burken, "Examining plant uptake and translocation of emerging contaminants using machine learning: implications to food security," Science of The Total Environment, vol. 698, p. 133999, 2020. 